\title{
Assessing the vulnerability of transport network to flood hazard using GIS analysis. Case study along Orient-East Med TEN-T Corridor, on Timiș-Cerna Valley, Romania
}

\section{Beniamin Stoica-Fuchs}

\begin{abstract}
"Simion Mehedinti" Doctoral School, Faculty of Geography, University of Bucharest, Romania;
\end{abstract} beniamin.stoica-fuchs@drd.unibuc.ro

Keywords: flash flood, road, railway, TEN-T European Network, Geographic Information Systems (GIS)

\begin{abstract}
In the context of current climate change, it is estimated that flood risk will increase significantly, with important consequences for the human habitat and transport networks. Research literature features a continuous concern both for the improvement of flood hazard modeling and for the quantification of economic costs specific to material and human damage caused by floods. In the present study, we intend to perform an analysis on the vulnerability of the transport network along the Orient-East Med (OEM) Corridor, part of the TEN-T Core network at European level. By integrating flood bands with high (10 years) and medium (100 years) probability of recurrence, as well as various typologies of the transport network in a GIS environment, we successfully identified and characterized road and railway sectors susceptible to flooding events. Vector overlay analysis and statistical methods were validated by means of local research literature, field observations and aerial imagery. Our results feature the geographic distribution and statistical characterization of transport infrastructure vulnerable to flood risk along Timiș-Cerna Valley, in south-western Romania. We also discuss the state of current flood risk mitigation measures for transport network in the study area, along with the importance of our research for regional and local spatial planning documents and investment prioritization activities. Similar spatially-enabled analysis could enable better protection for the current and proposed transport infrastructure and minimize the damaging effects of flash floods.
\end{abstract}

\section{Introduction}

Floods caused by rivers are a major danger to transport infrastructure at European level. Predictions made in various studies indicate that flood risk will increase due to global warming, a phenomenon accelerated by socio-economic development (Bubeck et al., 2019; Owusu and Agbozo, 2019).

Transport infrastructure, which is highly vulnerable to flooding, is perceived as "critical infrastructure". Considering the fact that the transport network is so vital to the functioning of society as a whole, the degradation of its functionality could have a major impact on the well-being, economic prosperity and security of the affected population (Liu et al., 2021). Although it is a topic of great interest and importance, spatial analyses on the impact of floods on transport networks is currently an insufficiently researched issue (Hackl et al., 2018).

In order to reduce the vulnerability of the national transport network and effectively prioritize infrastructure investments, it is vital to understand the impact of flood risk on the transport system (Pregnolato and Dawson, 2018; Papilloud et al., 2020). 
As computational capabilities and the level of detail specific to relevant data sets increases, object-based analysis replaces traditional research methods, which are mostly grid-based. The latter feature a high degree of generalization which, although acceptable for land use studies, lacks proper detail required by large-scale research. The discrete representation of the transport network in GIS environment as polylines requires a paradigm shift towards object-oriented evaluations. Object-based analysis, represented in this case by segments of the transport network, feature not only an improvement in the accuracy of the results, but also the possibility to design advanced estimations regarding flood-induced damage for various network typologies (Cai et al., 2007; Hankin et al., 2016). Modeling delays related to road or railway traffic, especially in urban environments, is also a topic that has gained increasing interest in recent years, in an attempt to understand the economic costs associated with floods (Pérez-Morales et al., 2019; Diakakis et al., 2020; He et al., 2021).

At European level, the importance of vulnerability studies concerning transport infrastructure in the context of climate change (Axelsen et al., 2016; Bles et al., 2016; van Ginkel et al., 2021) is underlined through the guidelines proposed in 2015 by the ROADAPT project (Roads for today adapted for tomorrow), implemented under the Transnational Road Research Program (CEDR). Alongside geomorphologic phenomena such as landslides, river floods are one of the most important hazards that affect transport infrastructure. In addition to the direct impact consisting of material damage and loss of human life, the resilience periods required for the transport network to return to its full functionality could vary from a few days to even a few weeks or months, depending on the magnitude of the event. Taking into consideration the fact that the response capacity is also limited due to the unforeseen nature of flash floods, vulnerability assessments on transport infrastructure could assist in preventing unfortunate loss of life and economic damage (Huang, 2018).

It has been noted that most flood risk studies concerning regional transport infrastructure focus on single point natural disasters along the network. Research on regional risk evaluation for flood disasters based on GIS was rarely reported (Qi et al., 2015). This paper features a regional evaluation of flood risk associated with transport infrastructure in south-western Romania, providing reference for flood risk mitigation initiatives. In this study we aim to perform an analysis on the vulnerability of transport infrastructure to flood hazard in the Timiș-Cerna Corridor, using thematic data provided by the National Administration of Romanian Waters (ANAR). The data associated with flood bands has been acquired during the national implementation of Directive 2007/60/EC on the assessment and management of flood risk. The preliminary assessment was conducted by March 2012, being followed closely by a second stage of designing hazard and risk maps for areas with significant flooding potential (about $16,000 \mathrm{~km}$ length of watercourses), until March 2014. The results of our study will feature an in-depth description of the geographic distribution of transport infrastructure vulnerable to flooding events in the study area. We will also discuss the current state of flood mitigation measures, as well as potential applications for the proposed methodology, in the context of spatial planning documents. The novelty of the present paper consists in the GIS-based identification of transport sectors vulnerable to flash floods along a mountainous section of the Orient-East Med (OEM) TEN-T Corridor. Our research could prove useful not only for the management of current transport network, but also for planning activities associated with transport development projects. Taking into consideration that the General Transport Master Plan of Romania proposes the development of an express route (DX2) as a better alternative to the current European road E70 (DN6), as well as the modernization of the main railway line between Orșova 
and Caransebeș, our results could improve route selection methodologies for future feasibility studies focused on the corridor.

\section{Study area}

The Timiș-Cerna Valley is located in the south-eastern part of Romania and covers an approximate area of $1227 \mathrm{~km}^{2}$. The corridor is bordered by the Southern Carpathians to the east, the Banat Mountains to the west, the Apuseni Mountains to the north and the Danube, on the Romanian-Serbian frontier. Considering national hydrographic basins and water administration areas, the Timiș-Cerna Valley is part of the Banat Hydrographic Administration, featuring three major hydrographic basins along the Cerna (south), Timiș (center) and Bistra (east) rivers. The Orient-East Med Corridor, part of the trans-European TEN-T Transport Network, has been developed along the Timiș-Cerna Valley between the municipalities of Caransebeș and Orșova. The main transport routes consist of the E70 highway $(91.3 \mathrm{~km})$ and a main railway (line number 900$)$, generally used for passenger transport (Figure 1).

The Timiș-Cerna Corridor is located in the upper basin of the Timiş river, which represents roughly about $20 \%$ of the reception basins in Romania. Almost all mountain tributaries in this sector feature strong torrential flow, imposed by slope and supply regime. Historical cartography studies have also showed that since XVIII ${ }^{\text {th }}$ century (1769-1772) until the present day, Timiş river has undergone many changes in terms of regularization (Burghelea et al., 2013). Seasonal flow of Timiș river at Teregova is distributed mostly towards the spring (44.3\%) and summer (23.8\%) months. The average liquid flow varies between $2.4 \mathrm{~m}^{3} / \mathrm{s}$ at Teregova and $10.9 \mathrm{~m}^{3} / \mathrm{s}$ at Caransebes (Linc, 2001). The highest values of maximum flow occur in May due to snowmelt and rainfall regime (Badea et al., 1983). An important feature of flow in the upper basin of the Timiş river is the regular appearance of annual flash floods, especially in the spring-summer season, between March and June (Badea et al., 1992; Oancea et al., 1987). The most representative flash floods were recorded between January and March 1957 , between 1978-1980 (86.4 m³ $/ \mathrm{s}$ at Caransebeş), in 1987 (397 m³ $/ \mathrm{s}$ - the highest value recorded in April at Caransebeş), in June 1989, in April 1998, in February 1999, as well as in April 2000, 2001 and 2005 (Costea, 2013a; Arba, 2012). Considering the importance of the Bistra river as a tributary to Timiș (Costea, 2013b), the study area has also been extended east of Caransebeș, along the Bistra Valley. Cerna river is located towards the southern region of the study area, between Băile Herculane and Orșova municipalities (Săndulache et al., 2017). It is a tributary of the Danube and features a mean flow rate between $12 \mathrm{~m}^{3} / \mathrm{s}$ at Băile Herculane and $21.4 \mathrm{~m}^{3} / \mathrm{s}$ at Topleț. Most recent flooding events occurred in April 2005, at the confluence with Bela Reca river, near Băile Herculane.

For the purpose of the present study, we will shortly describe the characteristics of 6 historical floods which were recorded in our study area and had a significant impact upon economic activities, buildings and transport infrastructure (Table 1). These flooding events took place in April 2000 and 2005, on Timiș (Teregova commune), Bistra (Bucova commune), Rusca (Rusca Montană commune), as well as on Cerna, downstream of the confluence with Bela Reca. In terms of spatial extension of floods, affected areas did not exceed $50,000 \mathrm{~km}^{2}$ and the maximum length of a flooded sector was about $41 \mathrm{~km}$, on the Bistra river in 2005. All 6 floods surpassed the transport capacity of the riverbed and, in a single case, along Timiș river in 2000, transport safety and defense infrastructure were overrun. Generally speaking, these floods were caused by high water levels due to heavy rainfall and, in two specific cases, they were caused by snow melting at the beginning of spring. Buildings were affected in all instances and flood defense and transport infrastructure suffered damage during 5 of these historical events. Given the fact that the 
frequency of historical floods was estimated at $10 \%$ and $2 \%$ (5 cases), corresponding to recurrence periods of 10 and 50 years respectively, we will only analyze the relationship between flood band levels and transport infrastructure for recurrence intervals of $1 \%$ (100 years) and 10\% (10 years).

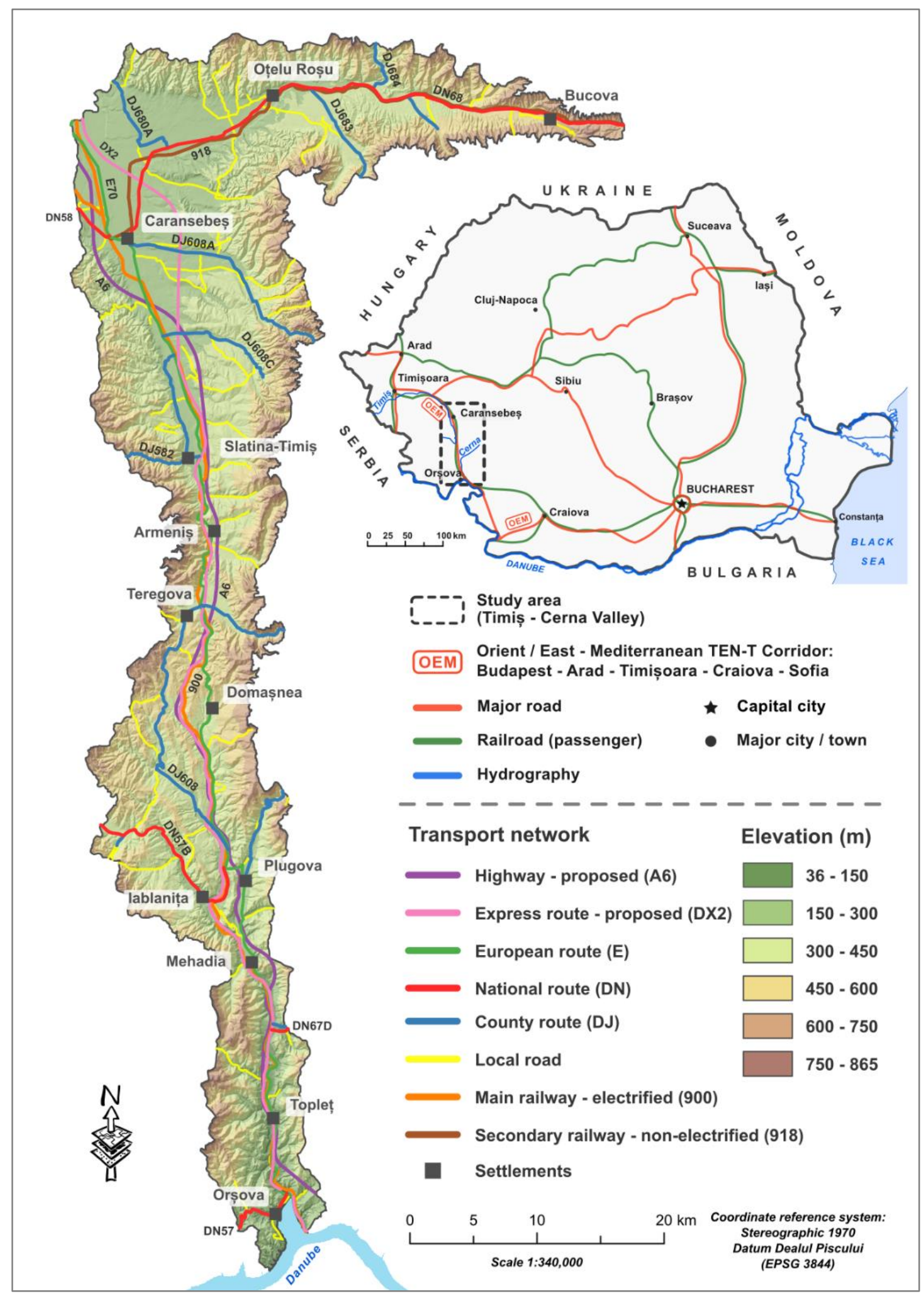

Figure 1. Transport network along Timiș-Cerna corridor and location of study area on national scale. 
Table 1. Characteristics of historical floods in the Timiș-Cerna Corridor.

\begin{tabular}{|c|c|c|c|c|c|c|c|}
\hline \multirow{6}{*}{$\begin{array}{c}\text { General } \\
\text { information }\end{array}$} & $\begin{array}{c}\text { Event } \\
\text { description }\end{array}$ & \begin{tabular}{|l|} 
Flash flood \\
April 2000 on \\
Timis river, \\
near \\
Teregova and \\
Cossteiu \\
settlements \\
\end{tabular} & \begin{tabular}{|l|} 
Flash flood \\
April 2005 on \\
Timis river, \\
near \\
Teregova and \\
Coșteiu \\
settlements \\
\end{tabular} & $\begin{array}{l}\text { Flash flood } \\
\text { April } 2000 \\
\text { on Bistra } \\
\text { river, near } \\
\text { Bucova }\end{array}$ & $\begin{array}{l}\text { Flash flood } \\
\text { April } 2005 \\
\text { Bistra river, } \\
\text { confluence } \\
\text { with Bucovița } \\
\text { river }\end{array}$ & $\begin{array}{l}\text { Flash flood } \\
\text { April 2005, } \\
\text { Rusca } \\
\text { river, near } \\
\text { Rusca } \\
\text { locality }\end{array}$ & \begin{tabular}{|l} 
Flash flood \\
April 2005, \\
Cerna \\
river, near \\
confluence \\
with Bela \\
Reca river \\
\end{tabular} \\
\hline & Debut date & 05.04 .2000 & 15.04 .2005 & 05.04 .2000 & 15.04 .2005 & \begin{tabular}{|l|l}
15.04 .2005 \\
\end{tabular} & 18.04 .2005 \\
\hline & \begin{tabular}{|c|}
$\begin{array}{c}\text { Event duration } \\
\text { (days) }\end{array}$ \\
\end{tabular} & 6 & 15 & 6 & 15 & 15 & 11 \\
\hline & \begin{tabular}{|c|}
$\begin{array}{c}\text { Flooded area } \\
\left(\mathrm{km}^{2}\right)\end{array}$ \\
\end{tabular} & 46.269 & 46.269 & 9.219 & - & - & - \\
\hline & \begin{tabular}{|c|} 
Flooded sector \\
length $(\mathrm{km})$
\end{tabular} & - & - & - & 41.152 & 2.629 & 14.564 \\
\hline & $\begin{array}{c}\begin{array}{c}\text { Recurrence } \\
\text { frequency }\end{array} \\
\end{array}$ & $2 \%$ & $2 \%$ & $2 \%$ & $2 \%$ & $2 \%$ & $10 \%$ \\
\hline \multirow{3}{*}{$\begin{array}{l}\text { Flash flood } \\
\text { source }\end{array}$} & Fluvial & $\mathrm{x}$ & $\mathrm{x}$ & $\mathrm{x}$ & $\mathrm{x}$ & $\mathrm{x}$ & $\mathrm{x}$ \\
\hline & Pluvial & $x$ & & & & & \\
\hline & Groundwater & & $\mathrm{x}$ & & & & \\
\hline \multirow{3}{*}{$\begin{array}{c}\text { Flooding } \\
\text { mechanism }\end{array}$} & $\begin{array}{l}\text { Exceeding } \\
\text { floodplain } \\
\text { capacity }\end{array}$ & $x$ & $x$ & $\mathrm{x}$ & $\mathrm{x}$ & $\mathrm{x}$ & $\mathrm{x}$ \\
\hline & $\begin{array}{c}\text { Exceeding safe } \\
\text { water levels }\end{array}$ & $x$ & & & & & \\
\hline & \begin{tabular}{|c|} 
Destroying \\
flood defence \\
infrastructure \\
\end{tabular} & $\mathrm{x}$ & & & & & \\
\hline \multirow{2}{*}{$\begin{array}{c}\text { Flood } \\
\text { characteristi } \\
\text { cs }\end{array}$} & $\begin{array}{l}\text { Spring flood } \\
\text { (freshet) }\end{array}$ & $x$ & & $\mathrm{x}$ & & & \\
\hline & $\begin{array}{l}\text { Remarkable } \\
\text { water levels }\end{array}$ & & $\mathrm{x}$ & & $\mathrm{x}$ & $\mathrm{x}$ & $\mathrm{x}$ \\
\hline \multirow{4}{*}{$\begin{array}{l}\text { Economic } \\
\text { damage } \\
\text { assessment }\end{array}$} & Buildings & $\mathrm{x}$ & $\mathrm{x}$ & $\mathrm{x}$ & $\mathrm{x}$ & $\mathrm{x}$ & $\mathrm{x}$ \\
\hline & Infrastructure & $\mathrm{x}$ & $\mathrm{x}$ & $\mathrm{x}$ & $\mathrm{x}$ & $\mathrm{x}$ & \\
\hline & Land use & $\mathrm{x}$ & $\mathrm{x}$ & & $\mathrm{x}$ & & \\
\hline & $\begin{array}{l}\text { Economic } \\
\text { activities }\end{array}$ & $\mathrm{x}$ & $\mathrm{x}$ & $\mathrm{x}$ & $\mathrm{x}$ & & \\
\hline
\end{tabular}

Source: National Administration for Romanian Waters (ANAR)

\section{Datasets and methodology}

The datasets used to analyze transport sections vulnerable to floods were acquired from several sources (Table 2). Data on the spatial extension of flood bands for high $(10 \%)$ and medium (1\%) probability scenarios were provided by the National Administration of Romanian Waters (ANAR), based on research performed by Aquaproiect Romania for the Banat Hydrographic Administration. Although the initial spatial resolution of this dataset was approx. $6.7 \mathrm{~m} /$ pixel, in order to simplify GIS overlay procedures, the data was resampled at $10 \mathrm{~m} /$ pixel. The transport network, consisting of the road and railway subsystems, was acquired by means digitization from the Topographic Map of Romania, at a scale of 1:50.000. Moreover, the route for the proposed express highway (DX2) between Drobeta-Turnu Severin and Lugoj was provided by the Ministry of Transportation and Infrastructure, as part of the list of development projects proposed through the General Transport Master Plan of Romania.

The role of flood hazard maps is to present the extension of potentially floodable areas, specific to flow rates with various probabilities of exceeding the river channel. On the other hand, risk maps are based on the analysis of information on the vulnerability of anthropic features exposed to the flood hazard (Albano et al., 2017). While the former feature the probability of an area being flooded, the latter emphasize the negative effects associated with the flood hazard, expressed in terms of the number of inhabitants in the affected areas and other quantifiable indicators regarding infrastructure damage, 
pollution risk, adverse effects on natural protected areas or other features of interest related with the human habitat.

At national level, both hazard and risk maps have been prepared in accordance with the provisions of Directive 2007/60/EC for three flooding scenarios:

- Low probability scenario (maximum flow rates with exceeding probability of $0.1 \%$, corresponding to floods which occur once in 1000 years);

- Medium probability scenario (maximum flow rates with exceeding probability of $1 \%$, corresponding to floods which occur once in 100 years);

- High probability scenario (maximum flow rates with exceeding probability of $10 \%$, specific to floods occurring once in 10 years).

Table 2. Characteristics of the data sets used for analysis.

\begin{tabular}{|l|c|l|c|}
\hline \multicolumn{1}{|c|}{ Datasets } & $\begin{array}{c}\text { Representation } \\
\text { type }\end{array}$ & \multicolumn{1}{c|}{ Source } & $\begin{array}{c}\text { Spatial } \\
\text { resolution }\end{array}$ \\
\hline $\begin{array}{l}\text { Flood bands for medium (1\%) } \\
\text { and high (10\%) recurrence } \\
\text { probability scenarios }\end{array}$ & Raster & $\begin{array}{l}\text { National Administration } \\
\text { for Romanian Waters } \\
\text { (ANAR) }\end{array}$ & $6.7 \mathrm{~m} / \mathrm{pixel}$ \\
\hline $\begin{array}{l}\text { Transport network (roads and } \\
\text { railways) }\end{array}$ & Polyline & $\begin{array}{l}\text { Topographic map of } \\
\text { Romania }\end{array}$ & $\begin{array}{c}1: 50,000 \\
\text { scale }\end{array}$ \\
\hline $\begin{array}{l}\text { Proposed route for Drobeta- } \\
\text { Turnu Severin - Lugoj } \\
\text { express road (DX2) }\end{array}$ & Polyline & $\begin{array}{l}\text { Ministry of } \\
\text { Transportation and } \\
\text { Infrastructure, General } \\
\text { Transport Master Plan of } \\
\text { Romania }\end{array}$ & - \\
\hline
\end{tabular}

The National Administration of Romanian Waters (ANAR) applied a series of advanced hydraulic modeling methods in order to design flood hazard maps, using data acquired though the National Flood Prevention, Protection and Mitigation Plan (PPPDEI), developed across 10 Water Basin Administrations (ABA). For the Banat Hydrographic Administration, where our study area is located, the initial spatial resolution of the thematic data used for hazard maps is $1 \mathrm{~m}$. The data associated with hazard models for the Danube was developed within the international project "DANUBE FLOODRISK Stakeholder oriented flood risk assessment for the Danube floodplains", financed through the South-East Europe Transnational Cooperation Program.

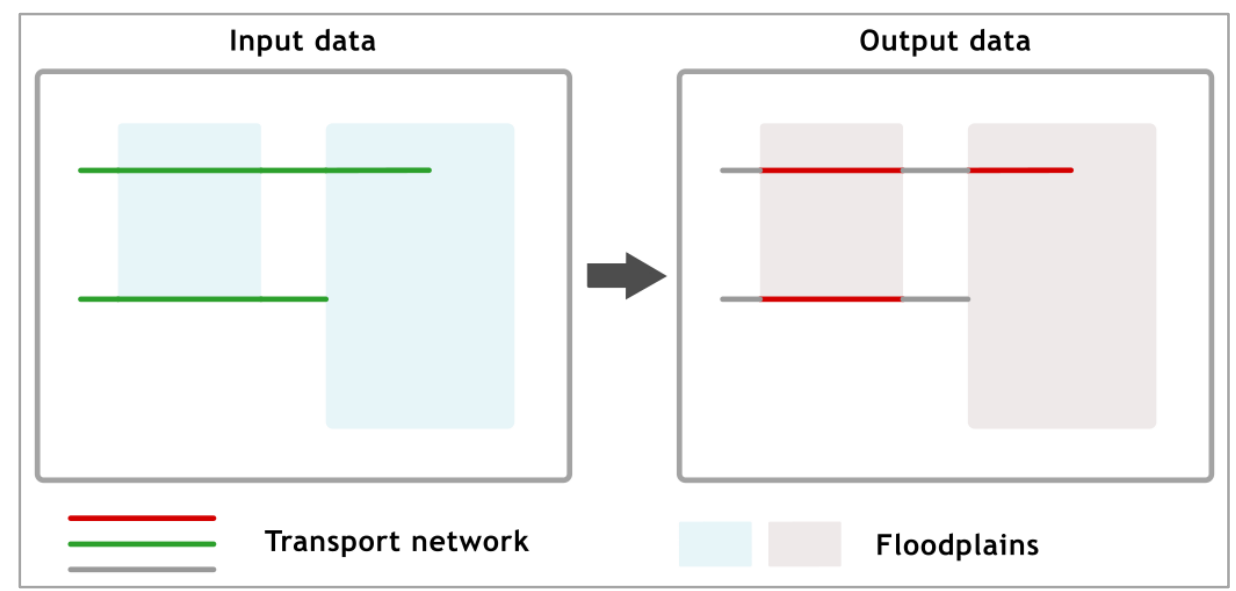

Figure 2. Use of the Intersect tool (ArcMap) for generating transport sectors vulnerable to flood scenarios with medium (1\%) and high probability $(10 \%)$ of recurrence.

Flood band modeling was conducted using a high-resolution LiDAR dataset, with a spatial resolution of $5 \mathrm{~m}$, complemented by field measurements and data collected from topographic maps. The flooding scenarios along the Danube are specific to events with recurrence periods of 30,100 and 1000 years, while the spatial resolution of hazard maps 
is estimated at approx. $20 \mathrm{~m} /$ pixel. For the purpose of our study, we acquired from ANAR only the datasets which were used for the design of flood hazard maps. These were subsequently resampled to $10 \mathrm{~m} /$ pixel in order to facilitate GIS analysis.

For the purpose of conducting overlay analysis along the transport network, flood band representations were converted from raster to vector format, using the Raster to Polygon (Conversion) tool in ArcMap. Then, by means of the Intersect tool (Analysis) from the same software package, it was possible to identify road and railway sectors vulnerable to flooding events (Figure 2). The length of vulnerable sectors was also calculated in GIS, based on the Stereographic 1970 national coordinate system. The information thus obtained was exported in tabular format for conducting additional statistical analysis with Microsoft Excel.

\section{Results}

Concerning the flood band with recurrence period of 10 years (10\%), we identified 31 sectors vulnerable to floods: one for the proposed express road, 4 European road sectors, 2 national road sectors, 5 county road sections and 11 local road sectors. Also, regarding the vulnerability of railway transport to floods, we identified 6 main railway sectors between Orșova and Caransebeș, as well as 2 secondary railway sectors between Caransebeș and Bucova. In terms of quantifiable aspects related to the affected sectors, we observed that the most vulnerable road categories are the proposed express route $(3,473 \mathrm{~m})$ and the European road E70 $(3,420 \mathrm{~m})$, followed by local roads $(936 \mathrm{~m})$ and national routes $(905 \mathrm{~m})$. The main electrified railway is vulnerable over a length of over $600 \mathrm{~m}$, while the secondary railway route is prone to flooding events over a length of just over $200 \mathrm{~m}$ (Figure 3). The maximum extents of floodable sectors were calculated at 3.4 $\mathrm{km}$ for the proposed express route (DX2), $2.6 \mathrm{~km}$ for the European road E70 and $817 \mathrm{~m}$ for national roads. For the remaining transport typologies, the maximum length of susceptible sections were estimated at roughly $150 \mathrm{~m}$ for county roads and the secondary railway, as well as $220 \mathrm{~m}$ for the main railway line. The minimum lengths of potentially affected sectors were similar both for the road and railway networks, ranging between 40 and $90 \mathrm{~m}$, with the exception of the proposed express route between Orșova and Caransebeș.

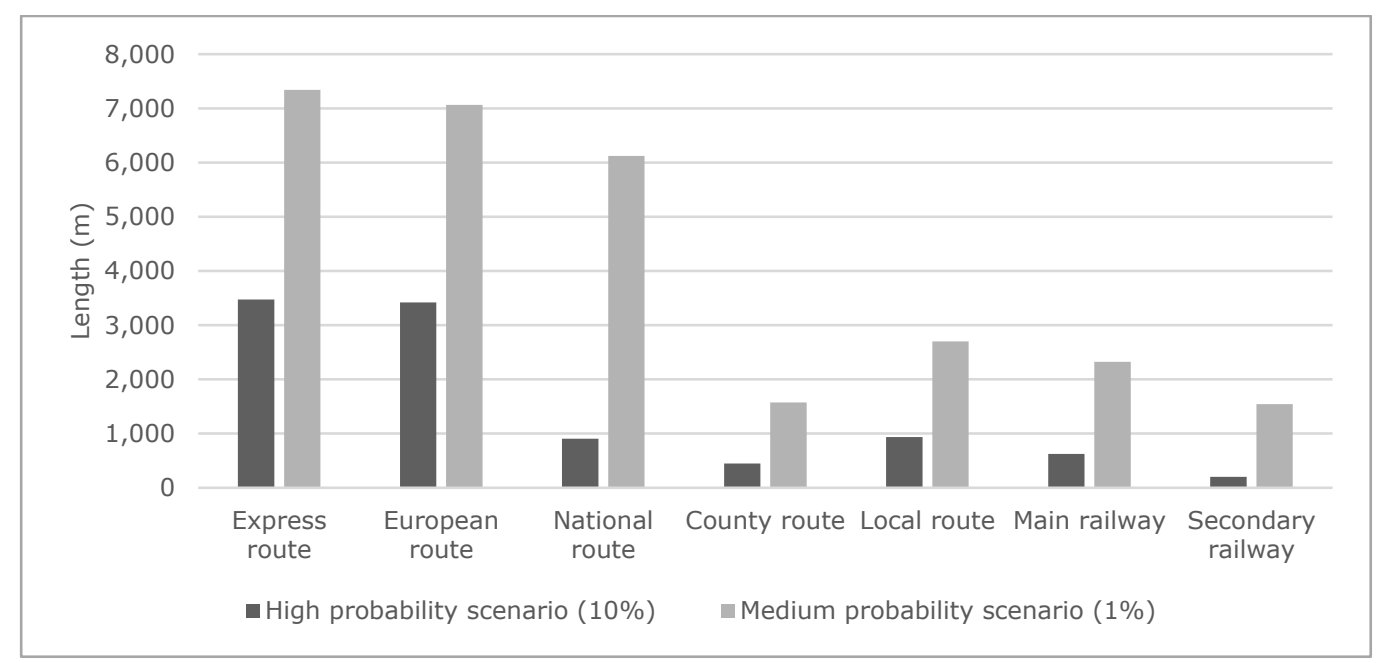

Figure 3. Total length $(\mathrm{km})$ of sectors included in flood scenarios with medium (1\%) and high probability $(10 \%)$ of recurrence, by main categories of the transport network.

The overlay analysis using the flood band with 100 years recurrence interval reveals a greater extension of potentially negative effects on transport infrastructure. In this 
context, almost $30 \mathrm{~km}$ of road and railway sections feature high potential for flood vulnerability, along 38 distinct sectors: one section of the proposed express road, 4 sectors of European road, 2 sections of national roads, 5 sections of county roads and no less than 15 sectors of local roads. The $2.3 \mathrm{~km}$ of vulnerable main railway are divided into 7 sections, while the secondary railway is vulnerable in 4 distinct sectors, extending over a length of $1.5 \mathrm{~km}$. The DX2 express route could be affected by potential floods along a total length of $7.34 \mathrm{~km}$, similarly to the existing European road $(7.06 \mathrm{~km})$ and the national roads located in the study area $(6.12 \mathrm{~km})$. Considering the peripheral location of the county and communal roads, mainly outside the major floodplains, the length of potentially vulnerable segments is estimated at only $1.57 \mathrm{~km}$ and $2.7 \mathrm{~km}$ respectively. The maximum lengths corresponding to floodable sectors in the medium probability scenario $(1 \%)$ are $7.4 \mathrm{~km}$ for the DX2 express motorway, approx. $4.1 \mathrm{~km}$ for the European road E70 and $5.9 \mathrm{~km}$ for national roads. County and communal roads could be affected on sections extending over $700 \mathrm{~m}$ and $350 \mathrm{~m}$ respectively. The maximum length of a vulnerable railway sector in this scenario is about $1.6 \mathrm{~km}$ for the main railway and $1.18 \mathrm{~km}$ for the secondary railroad. Furthermore, the minimum extents of affected sections were estimated as ranging between $26 \mathrm{~m}$ (electrified main railway) and $200 \mathrm{~m}$ (national roads).

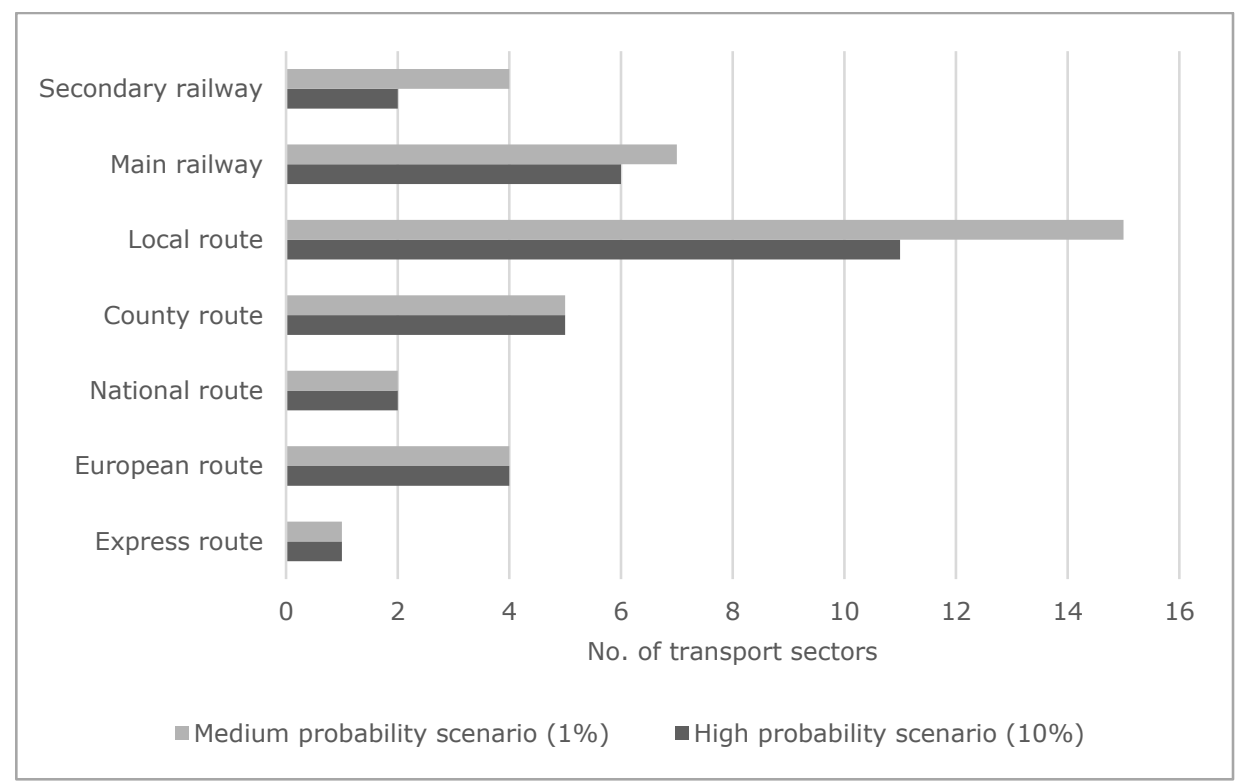

Figure 4. Total number of sectors affected in flood scenarios with medium (1\%) and high probability $(10 \%)$ of recurrence, by main typologies of the transport network.

It should also be noted that the number of sectors that may be affected by floods in both scenarios remains fairly similar, both for national and county roads, as well as for the European route E70 and the proposed express route (Figure 4). This situation points out to the continuity of flood bands when transitioning from one scenario to another, which determines the expansion of floodable road and railway sectors without additional spatial fragmentation. However, the difference between the two scenarios is quite visible when we analyze the geometric extent of exposed sectors. Considering the road network, with respect to communal and county roads, as well as for European and express routes, the length of vulnerable sectors doubles or even triples. An exceptional situation is encountered in the case of national roads, which feature a total length of vulnerable sectors that is about 6.7 times higher in the medium probability scenario, although the number of potentially affected road segments is unchanged. 


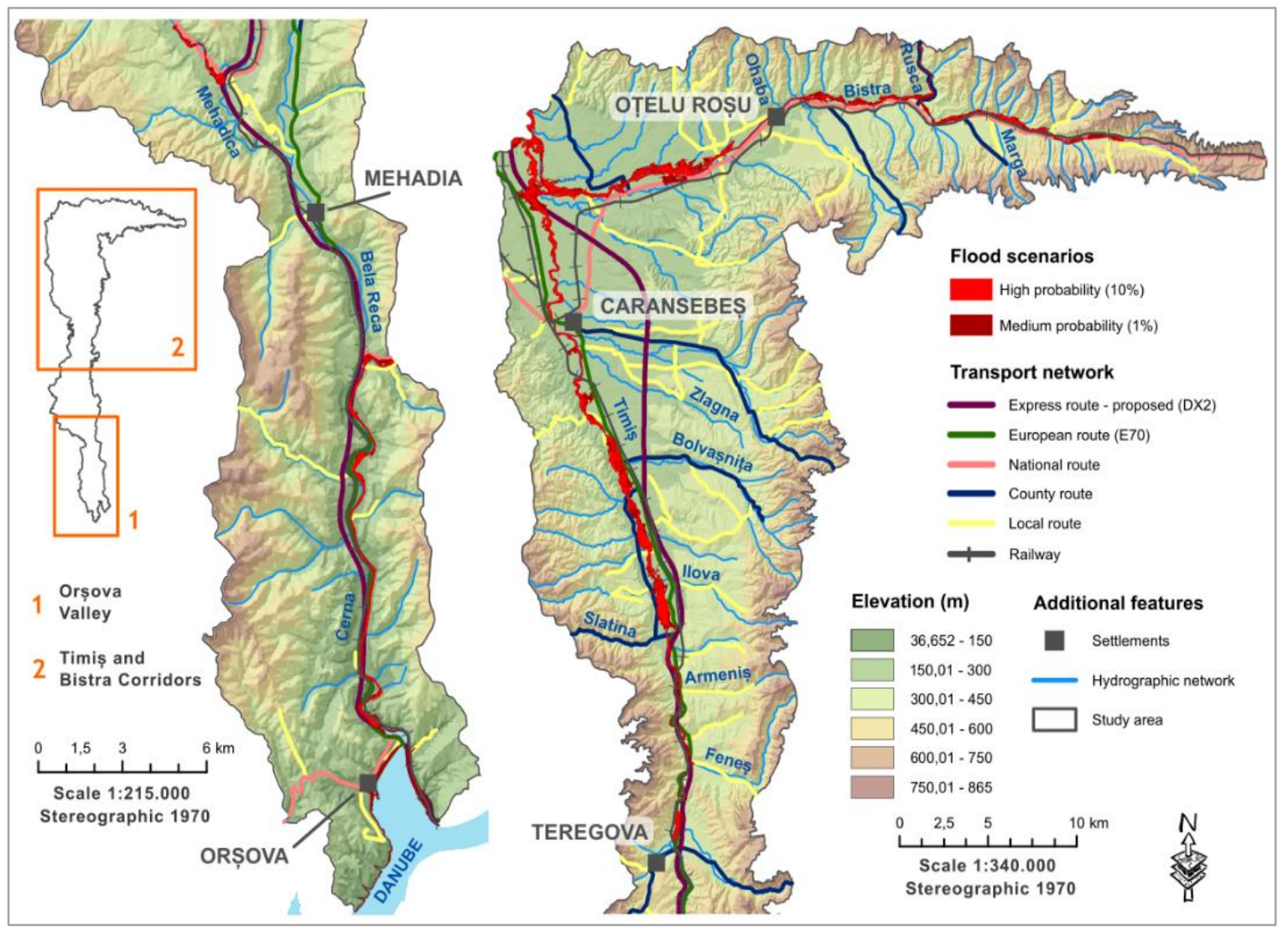

Figure 5. Transport network in relation to flood scenarios with medium and high probability of recurrence in the Timiș-Cerna Corridor (source: ANAR).

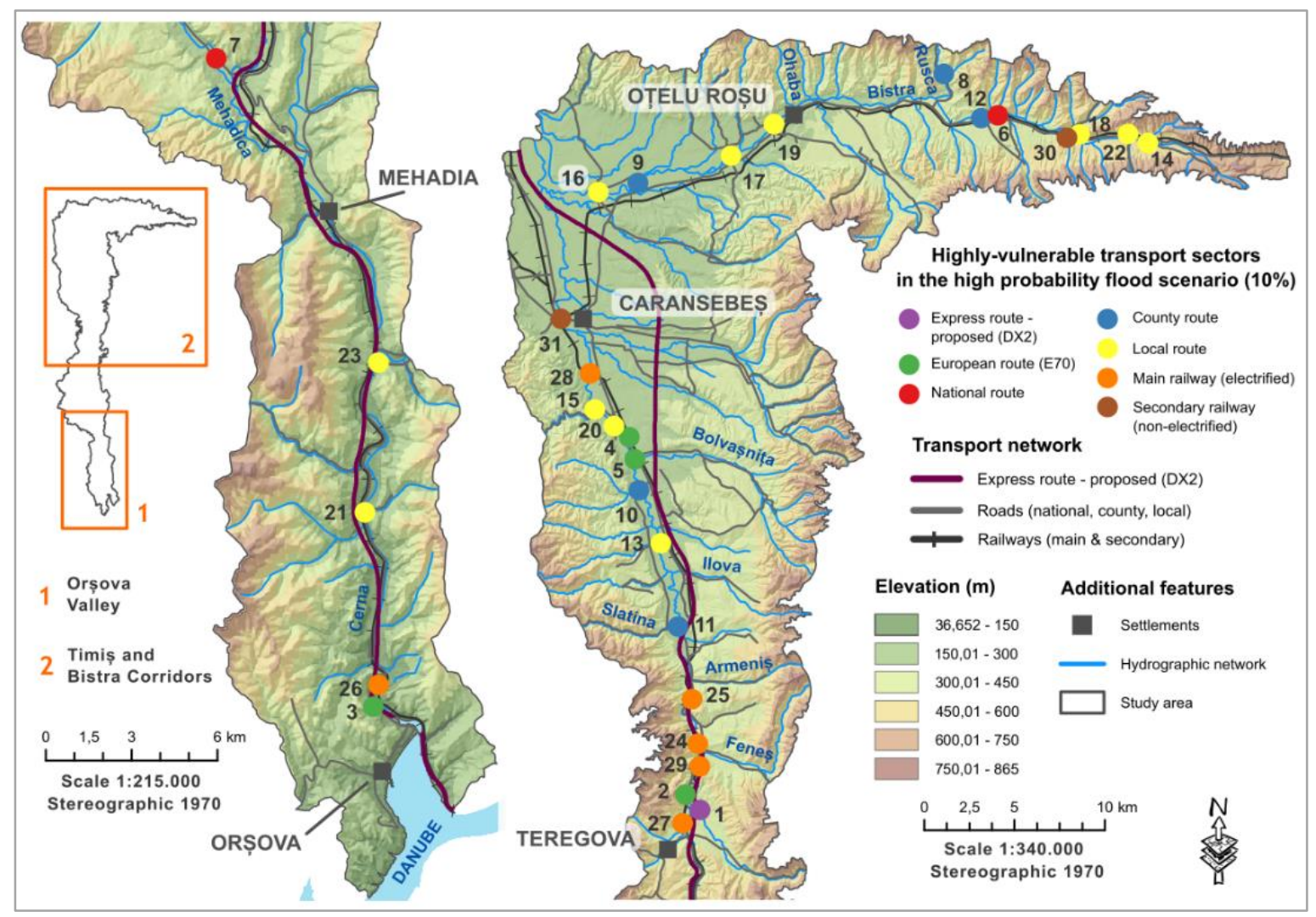

Figure 6. Critical points in the transport network, vulnerable to floods in the high probability scenario (10\%), along the Timiș-Cerna Corridor. 
Table 3. List of road and railway sectors vulnerable in the medium (1\%) and high (10\%) flood probability scenarios, by main categories of the transport network.

\begin{tabular}{|c|c|c|c|c|c|c|c|}
\hline \multicolumn{4}{|c|}{ High probability scenario $(10 \%)$} & \multicolumn{4}{|c|}{ Medium probability scenario $(1 \%)$} \\
\hline No. & Network typology & Indicative & Length $(\mathrm{m})$ & No. & Network typology & Indicative & Length $(\mathrm{m})$ \\
\hline 1 & Express route & $\mathrm{D} \times 2$ & $3,473.12$ & 1 & Express route & $\mathrm{D} \times 2$ & $7,339,46$ \\
\hline 2 & European route & E7 O/DN6 & $2,671,44$ & 2 & European route & E70/DN6 & $4,175.98$ \\
\hline 3 & European route & E70/DN6 & 431.48 & 3 & European route & E70/DN6 & $2,193.50$ \\
\hline 4 & European route & E70/DN6 & 277.30 & 4 & European route & E70/DN6 & 654.66 \\
\hline 5 & European route & E70/DN6 & 40.27 & 5 & European route & E70/DN6 & 40.27 \\
\hline 6 & National route & DN68 & 817.73 & 6 & National route & DN68 & $5,921,30$ \\
\hline 7 & National route & DN57B & 88.11 & 7 & National route & DN57B & 199.30 \\
\hline 8 & County route & DJ684 & 147.30 & 8 & County route & DJ684 & 704.36 \\
\hline 9 & County route & DJ680A & 91.46 & 9 & County route & DJ $608 \mathrm{C}$ & 449.64 \\
\hline 10 & County route & DJ608C & 90.63 & 10 & County route & DJ680A & 267.13 \\
\hline 11 & County route & DJ582 & 70.94 & 11 & County route & DJ582 & 81.08 \\
\hline 12 & County route & DJ684A & 48.43 & 12 & County route & DJ684A & 73.73 \\
\hline 13 & Local route & $D \subset 20$ & 186.75 & 13 & Local route & - & 351.70 \\
\hline 14 & Local route & - & 131.24 & 14 & Local route & - & 350.11 \\
\hline 15 & Local route & $D \subset 13$ & 93.51 & 15 & Local route & $D c 13$ & 342.02 \\
\hline 16 & Local route & $\mathrm{Dc4}$ & 93.39 & 16 & Local route & $D \subset 20$ & 262.83 \\
\hline 17 & Local route & - & 91.06 & 17 & Local route & Dc4 & 250.17 \\
\hline 18 & Local route & $D<1$ & 81.85 & 18 & Local route & $D \subset 1$ & 205.10 \\
\hline 19 & Local route & - & 68.73 & 19 & Local route & - & 202.25 \\
\hline 20 & Local route & $D c 14$ & 55.87 & 20 & Local route & - & 179.13 \\
\hline 21 & Local route & - & 51.21 & 21 & Local route & - & 126.53 \\
\hline 22 & Local route & - & 42.14 & 22 & Local route & - & 120.07 \\
\hline 23 & Local route & - & 40.45 & 23 & Local route & - & 68.91 \\
\hline 24 & Main railway & 900 & 218.40 & 24 & Local route & Dc18 & 61.64 \\
\hline 25 & Main railway & 900 & 113.68 & 25 & Local route & - & 61.36 \\
\hline 26 & Main railway & 900 & 96.16 & 26 & Local route & - & 60.67 \\
\hline 27 & Main railway & 900 & 84.05 & 27 & Local route & De14 & 59.65 \\
\hline 28 & Main railway & 900 & 61.59 & 28 & Main railway & 900 & $1,646.87$ \\
\hline 29 & Main railway & 900 & 49.92 & 29 & Main railway & 900 & 218.40 \\
\hline 30 & Secondary railway & 918 & 148.79 & 30 & Main railway & 900 & 202.48 \\
\hline 31 & Secondary railway & 918 & 54.01 & 31 & Main railway & 900 & 117.77 \\
\hline & & & & 32 & Main railway & 900 & 61.59 \\
\hline & & & & 33 & Main railway & 900 & 49.92 \\
\hline & & & & 34 & Main railway & 900 & 26.02 \\
\hline & & & & 35 & Secondary railway & 918 & $1,180.58$ \\
\hline & & & & 36 & Secondary railway & 918 & 141.57 \\
\hline & & & & 37 & Secondary railway & 918 & 121.14 \\
\hline & & & & 38 & Secondary railway & 918 & 98.56 \\
\hline
\end{tabular}

The length of the affected sectors for the main railway increases almost 4 times in the $1 \%$ recurrence scenario. Similarly, the secondary railway between Caransebes and 
Bucova could be affected on a distance which is 7 to 8 times higher than the one specific to the high probability flood prediction.

Regarding the spatial distribution of vulnerable transport sectors, we notice they are mainly located along the floodplains of Cerna, Timis and Bistra rivers (Figure 5). The critical points corresponding to the secondary transport network are located in the proximity of intersections with the main transport infrastructure, represented by the European road E70 and national roads. Also, the most flood-susceptible sectors are located along the Timiș river, where the higher density of secondary hydrographic network and more significant flow rates increase flood band extension. On the other hand, the Cerna Valley features an opposite situation, with a considerably lower number of critical points along the infrastructure network (Figure 6).

Overall, the spatial distribution of critical points is constant when transitioning between the two flooding scenarios (Table 3). We notice an increase in the number of affected railway sectors on the upper course of Timiș river, between Teregova and Slatina-Timiș. The number of vulnerable secondary railway sectors on the upper course of Bistra river also features an increase. Moreover, in the medium flood probability $(1 \%)$ scenario, the number of potentially vulnerable sectors increases substantially along the Danube, as the transport network is exposed to higher risk levels (Figure 7). Overall, Cerna Valley is least affected by the transition between flooding scenarios, featuring a constant number of critical points along the transport network.

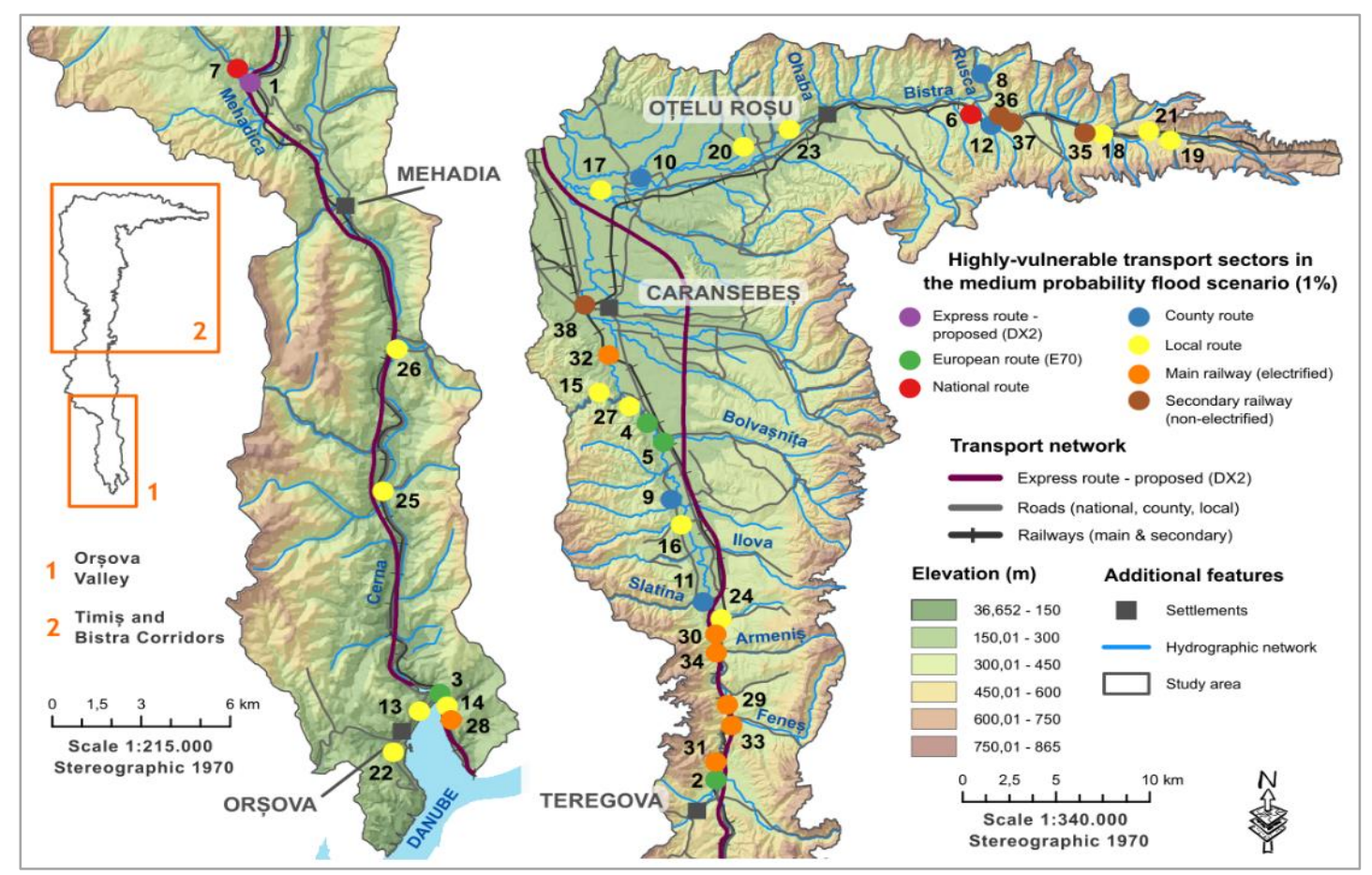

Figure 7. Critical points in the transport network, vulnerable to floods in the medium probability scenario (1\%), along the Timiș-Cerna Corridor.

\section{Discussion}

The prospect of researching the complex interactions at the interface of man-made infrastructure and natural features should present not only theoretical results, but also an applicative approach. The utility of the present study extends beyond the methodological aspects, to practical ways in which spatial analysis could be integrated in national or regional spatial planning documents. Because the study area is located mostly on the administrative territory of Caraș-Severin County, the most appropriate means to illustrate the applicability of our research is to relate to the provisions of its regional 
Spatial Plan (PATJ). The document features the spatial distribution and characteristics of areas vulnerable to various natural hazards, such as seismic activity, landslides, forest fires, snowfalls, avalanches or floods. The data related to floodable areas is mentioned in a descriptive form, vulnerable sectors being located at the level of river basins, watercourses and localities. In this context, the hydrotechnical works carried out along rivers with high flooding potential are also mentioned. Considering the critical points located along the transport network in our study, three main development projects related to vulnerable watercourse sections were identified:

- The regularization of Bistra river in the Bucova - Oțelu Roșu sector (2.5 million euros). This section features, in the high probability flooding scenario, a national road sector (DN 68, critical point no. 6) and a county road sector (DJ 684A), 3 communal road sectors (nos. 14, 18, 22) and one secondary railway sector (no. 30). These are joined by two secondary railway critical points (nos. 36 and 37), featured in the medium probability scenario.

- The engineering works on the right bank of Bistra river, between Oțelu Roșu and the confluence with Timiș river (1.5 million euros). In this section we identified two communal road sectors (nos. 16 and 17, as well as nos. 17 and 20) and a county road sector (DJ 680A, nos. 9 and 10) vulnerable to floods in both scenarios.

- The regularization of Cerna river downstream of Băile Herculane (3 million euros), where we located a single vulnerable road sector, at the intersection with the European route E70 (critical points no. 23 and 26 respectively).

A series of other projects aiming to restore the resilience of transport infrastructure to floods were carried out by the National Company for Investment (Compania Națională de Investiții S.A.), through the National Program for Constructions of Public or Social Interest (PNCIPS). A number of infrastructure rehabilitation projects were financed through the "Emergency works" subprogram and implemented between 2015 and 2018 in our study area. Among these, we mention the reconstruction of affected road infrastructure in the Topleț and Bucoșnița communes, along with the development of defensive engineering works in the Marga commune.

Taking into account vulnerable infrastructure sections identified in our study, the list of flood mitigation projects does not include important sectors located along the Timiș (DJ 582 and DJ 608C) and Rusca rivers (DJ 684). These correspond to critical points no. 8, 10 and 11 in the high probability scenario (10\%) and points no. $8,9,11$ in the medium probability scenario ( $1 \%)$.

The vulnerability of major road and railway infrastructure to flash flood events is not mentioned in planning documents, either at national or regional level. The National Spatial Plan, approved by means of Law no. 575/2001, approaches the issue of flood risk by identifying vulnerable territorial administrative units (TAUs). This is required in order to ensure that project funding by central authorities is supported by a legal framework, which would help the prioritization and allocation of funds to the most susceptible areas. However, the vulnerability of transport infrastructure to flooding is not considered to be an important criterion for risk assessment at this scale.

The Management Plan of the Banat Hydrographic Administration, developed at regional scale, features a brief evaluation of vulnerable transport infrastructure. About $216 \mathrm{~km}$ of roads (national/European $-51 \mathrm{~km}$, county roads $-88 \mathrm{~km}$, local roads -77 $\mathrm{km}$ ), as well as $52 \mathrm{~km}$ of railways could be vulnerable to flooding in the medium probability $(1 \%)$ scenario. However, no detailed spatial analysis has been carried out in order to accurately identify vulnerable sectors. Therefore, the main objective of the plan is to maintain the length of vulnerable road and railway sectors as close as possible to current levels. The proposed measures for reducing the risk associated with transport infrastructure are also fairly general, focusing on the development of specific regulations 
for future road and railway engineering projects, in conjunction with the Ministry of Transport and Infrastructure.

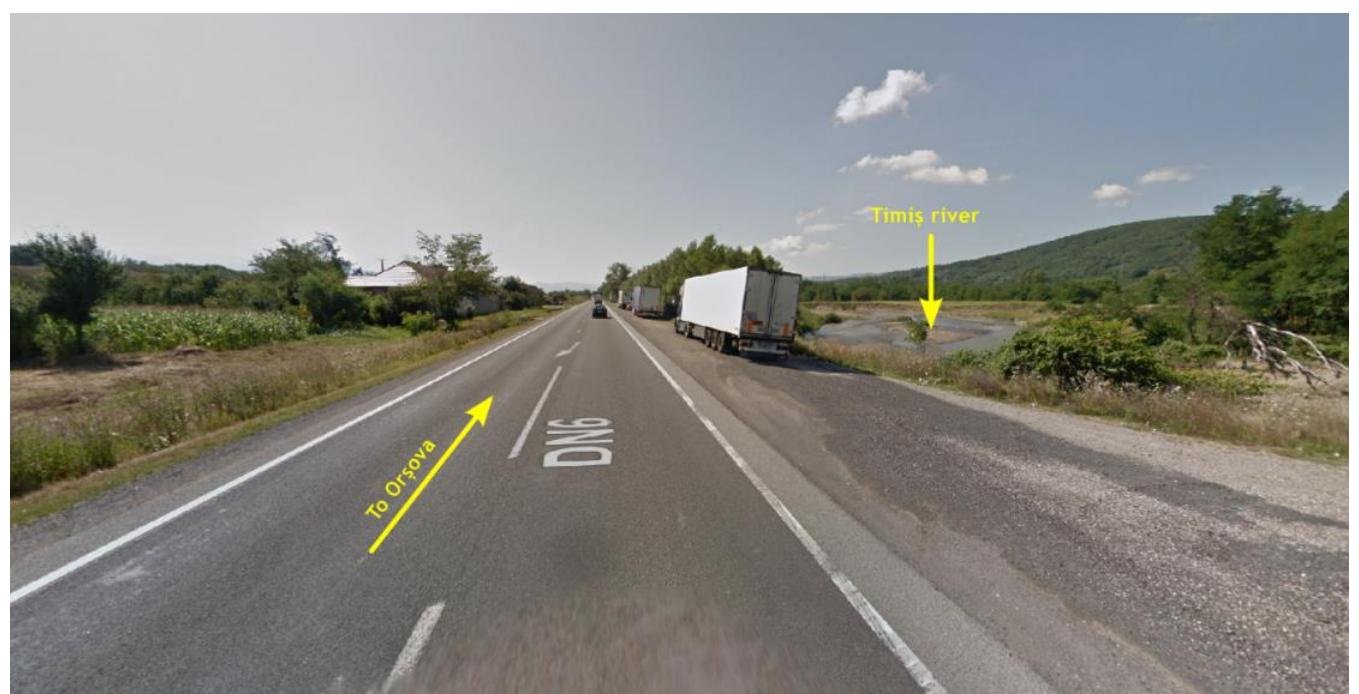

Figure 8. Critical point no. 4 (scenario of medium flood probability - 1\%) along European Road E70/DN6 and Timiș river (source: Google Street View, August 2019).

Given the specific dynamics of floodplain landscapes, vulnerability of main transport infrastructure is far from being solved (Figure 8 ). In this context, aerial imagery represents an outstanding analysis instrument which complements field studies and could help monitor the diachronic evolution of erosion and accumulation processes which shape floodplains and influence flood risk potential (Figure 9).

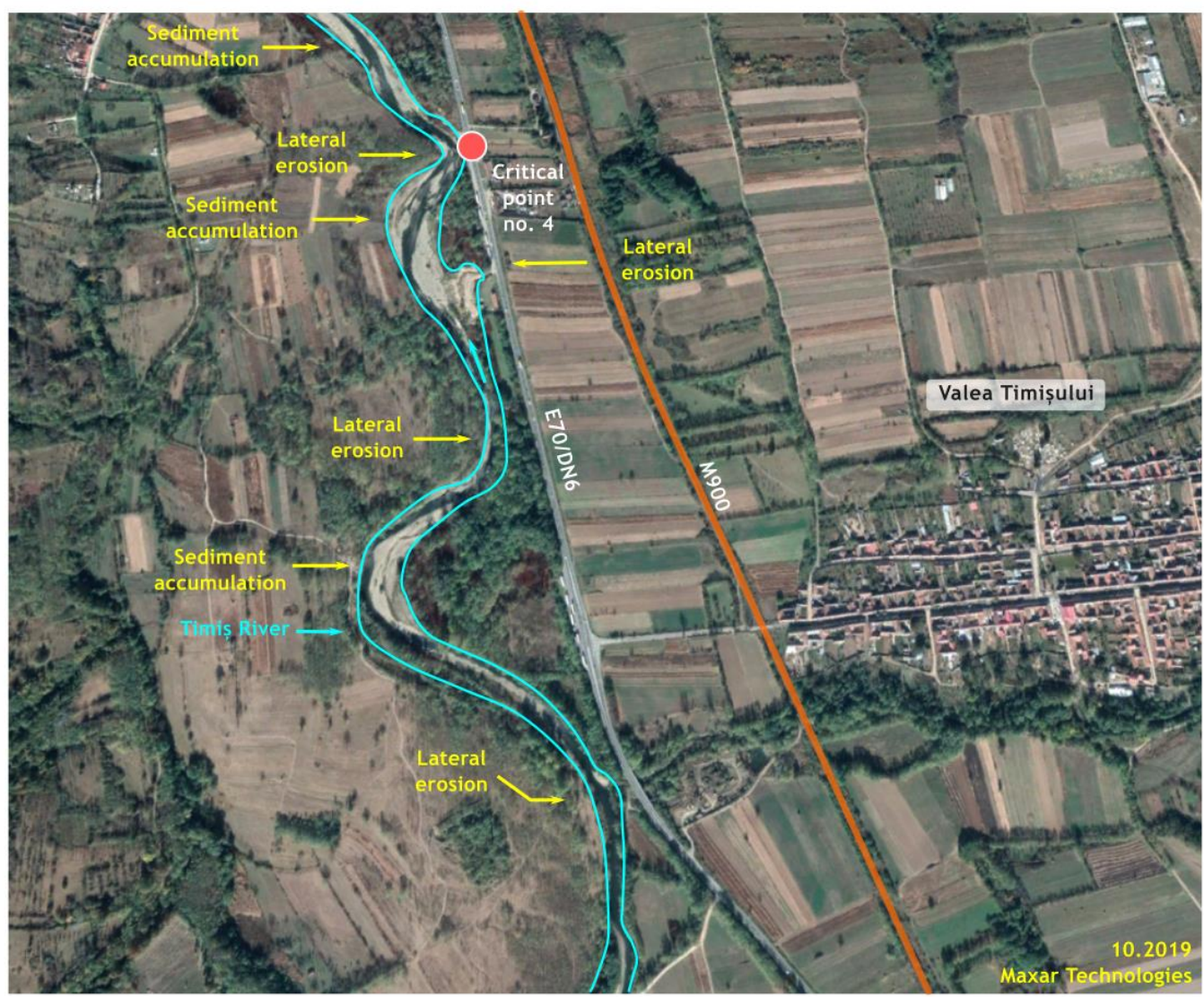

Figure 9. Aerial view of critical point no. 4 (medium probability scenario) along European Route E70/DN6, main railway line (M900) and Timiș river (source: Maxar Technologies, October 2019). 
The results of our study could be a starting point for promoting the transition from the current risk-reduction approach, based on soft measures, to a more practical strategy, focused on tangible projects. This change of paradigm could help decrease the number and extent of susceptible transport sectors, which is actually the ultimate goal of the management plan.

In terms of actual technical solutions which could be implemented in order to mitigate flood vulnerability in the study area, we believe there are still opportunities for further enhancements. For instance, the development of green forest belts along floodplains for draining excess humidity could prove an efficient measure for lowering flood risk. Protection of transport infrastructure with appropriate engineering solutions (e.g.: gabions, ditches) should also be a priority. Future development projects aimed at expanding the current transport network should also avoid high-vulnerability areas along the corridor. We believe that our methodology could complement existing planning policies, by providing an analytic tool to support relevant authorities in exploring long-term opportunities for the development of a more sustainable and resilient transport network (Gil and Steinbach, 2008).

\section{Conclusions}

In the context of accelerating climate changes and their associated high-risk events, studying the vulnerability of transport infrastructure to floods is an important step in ensuring the resilience of this vital system for the proper functioning of human habitat and the prevention of economic damage and loss of life. The research presented in this paper features an identification of transport sectors vulnerable to flood hazard in the Timiș-Cerna Valley, along the Orient-East Med TEN-T Corridor. By means of GIS overlay analysis, vulnerable road and railway sectors were extracted along rivers with high $(10 \%)$ and medium (1\%) probability of flood recurrence. We also presented this sensitive topic as addressed in spatial planning documents, emphasizing the main initiatives implemented by public authorities for mitigating the vulnerability of transport infrastructure to flood events. Our results could be further detailed in order to develop estimates regarding the extent of economic damage that may be caused by floods, depending on various transport network typologies. Along with the location of vulnerable sectors, this information could prove useful for the implementation of management plans, as well as for the effective prioritization of development projects at regional and local level, in order to ensure the long-term integrity and sustainability of the transport system.

\section{References}

1. Albano, R., Mancusi, L., Abbate, A. (2017). Improving flood risk analysis for effectively supporting the implementation of flood risk management plans: The case study of "Serio" Valley. Environmental Science \& Policy, 75, 158-172. https://doi.org/10.1016/j.envsci.2017.05.017.

2. Arba, A. M. (2012). The periods with pluviometric surplus from the Timiş hydrographical basin (1965-2009). Forum Geografic, XI 209-213. https://doi.org/10.5775/fg.2067-4635.2012.080.d

3. Axelsen, C., Grauert, M., Liljegren, E., Bowe, M., Sladek, B. (2016). Implementing Climate Change Adaptation for European Road Administrations. Transportation Research Procedia, 14, 51-57. https://doi.org/10.1016/j.trpro.2016.05.040.

4. Badea, L., Bugă, D. (Eds.). (1992). Geografia României, vol. IV, Regiunile pericarpatice, Editura Academiei Române, București.

5. Badea, L., Gâştescu, P., Velcea, V. (1983). Geografia României. Geografie fizică, Editura Academiei, București. 
6. Bles, T., Bessembinder, J., Chevreuil, M., Danielsson, P., Falemo, S., Venmans, A., Ennesser, Y., Löfroth, H. (2016). Climate Change Risk Assessments and Adaptation for Roads - Results of the ROADAPT Project. Transportation Research Procedia, 14, 58-67. https://doi.org/10.1016/j.trpro.2016.05.041.

7. Bubeck, P., Dillenardt, L., Alfieri, L., Feyen, L., Thieken, A. H., Kellermann, P. (2019). Global warming to increase flood risk on European railways. Climatic Change, 155(1), 19-36. https://doi.org/10.1007/s10584-019-02434-5.

8. Burghelea, B., Bănăduc, D., Curtean-Bănăduc, A. (2013). The Timiş River Basin (Banat, Romania) - natural and anthropogenic elements. A study case - management challenges. Transylvanian Review of Systematical and Ecological Research, 15(3), 173-206. https://doi.org/10.2478/trser-2013-0041.

9. Cai, H., Rasdorf, W., Tilley, C. (2007). Approach to Determine Extent and Depth of Highway Flooding. Journal of Infrastructure Systems, 13(2), 157-167. https://doi.org/10.1061/(ASCE)1076-0342(2007)13:2(157).

10. Costea, M. (2013a). Some Geomorphologic aspects along the Timiş River in the Romanian sector. Transylvanian Review of Systematical and Ecological Research, 15(3), 23-32. https://doi.org/10.2478/trser-2013-0030.

11. Costea, M. (2013b). Spatial and temporal features of the Timiș River (Banat, Romania) liquid flow regime. Transylvanian Review of Systematical and Ecological Research, 15(3), 1-12. https://doi.org/10.2478/trser-2013-0028.

12. Diakakis, M., Boufidis, N., Salanova Grau, J. M., Andreadakis, E., Stamos, I. (2020). A systematic assessment of the effects of extreme flash floods on transportation infrastructure and circulation: The example of the 2017 Mandra flood. International Journal of Disaster Risk Reduction, 47, 101542. https://doi.org/10.1016/j.ijdrr.2020.101542.

13. Gil, J., Steinbach, P. (2008). From flood risk to indirect flood impact: Evaluation of street network performance for effective management, response and repair. Flood Recovery, Innovation and Response, I, 335-344. London, England: WIT Press. https://doi.org/10.2495/FRIAR080321.

14. Hackl, J., Lam, J. C., Heitzler, M., Adey, B. T., Hurni, L. (2018). Estimating network related risks: A methodology and an application in the transport sector. Natural Hazards and Earth System Sciences, 18(8), 2273-2293. https://doi.org/10.5194/nhess-18-2273-2018.

15. Hankin, B., Craigen, I., Rogers, W., Morphet, J., Bailey, A., Whitehead, M. (2016). Flood Risk to the Strategic Road Network in England. E3S Web of Conferences, 7, 10001. https://doi.org/10.1051/e3sconf/20160710001.

16. He, Y., Thies, S., Avner, P., Rentschler, J. (2021). Flood impacts on urban transit and accessibility-A case study of Kinshasa. Transportation Research Part D: Transport and Environment, 96, 102889. https://doi.org/10.1016/j.trd.2021.102889.

17. Huang, G. (2018). Enhancing Dialogue between Flood Risk Management and Road Engineering

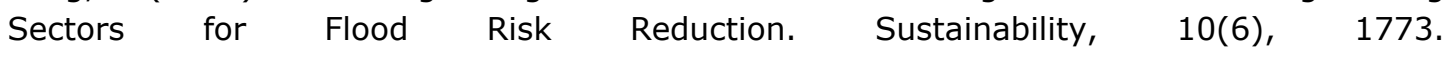
https://doi.org/10.3390/su10061773.

18. Linc, R. (2001). Culoarul Timiş-Cerna. Studiu de geografie fizică, PhD Thesis, Babeș-Bolyai University, Faculty of Geography, Cluj-Napoca.

19. Liu, J., Shi, Z., Tan, X. (2021). Measuring the dynamic evolution of road network vulnerability to floods: A case study of Wuhan, China. Travel Behaviour and Society, 23, 13-24. https://doi.org/10.1016/j.tbs.2020.10.009.

20. Oancea, D., Velcea, V. (Eds.). (1987). Geografia României, vol. III, Carpații şi Depresiunea Transilvaniei, Editura Academiei Române, București.

21. Owusu, A. B., Agbozo, M. (2019). Application of Geographic Information Systems for Flood Risk Analysis: A Case Study from Accra Metropolitan Area. Present Environment and Sustainable Development, 13(1), 81-97. https://doi.org/10.2478/pesd-2019-0007.

22. Papilloud, T., Röthlisberger, V., Loreti, S., Keiler, M. (2020). Flood exposure analysis of road infrastructure - Comparison of different methods at national level. International Journal of Disaster Risk Reduction, 47, 101548. https://doi.org/10.1016/j.ijdrr.2020.101548 
23. Pérez-Morales, A., Gomariz-Castillo, F., Pardo-Zaragoza, P. (2019). Vulnerability of Transport Networks to Multi-Scenario Flooding and Optimum Location of Emergency Management Centers. Water, 11(6), 1197. https://doi.org/10.3390/w11061197.

24. Pregnolato, M., Dawson, D. A. (2018). Adaptation investments for transport resilience: Trends and recommendations. International Journal of Safety and Security Engineering, 8(4), 515527. https://doi.org/10.2495/SAFE-V8-N4-515-527.

25. Qi, H.-L., Tian, W.-P., Li, J.-C. (2015). Regional Risk Evaluation of Flood Disasters for the Trunk-Highway in Shaanxi, China. International Journal of Environmental Research and Public Health, 12(11), 13861-13870. https://doi.org/10.3390/ijerph121113861.

26. Săundulache, I., Grecu, F., Săndulache, C., Irimescu, A. (2017). Cerna River terraces between Băile Herculane and Orșova. Analele Universității București: Geografie, 2017, 17-38.

27. van Ginkel, K. C. H., Dottori, F., Alfieri, L., Feyen, L., Koks, E. E. (2021). Flood risk assessment of the European road network. Natural Hazards and Earth System Sciences, 21(3), 10111027. https://doi.org/10.5194/nhess-21-1011-2021.

(C) 2021 by the authors. Licensee UAIC, Iasi, Romania. This article is an open access article distributed under the terms and conditions of the Creative Commons Attribution (CC BY-NC-ND) license (https://creativecommons.org/licenses/by-nc-nd/4.0). 